\title{
Ringworm Infection in Cattle and Horses in Jordan
}

\author{
F. K. AL-ANI, F. A. YOUNES, O. F. AL-RAWASHDEH \\ Department of Veterinary Clinical Sciences, Faculty of Veterinary Medicine, \\ Jordan University of Science and Technology, Irbid, Jordan \\ Received May 8, 2001 \\ Accepted February 13, 2002 \\ Abstract
}

Al-Ani F. K., F. A. Younes, O. F. Al-Rawashdeh: Ringworm Infection in Cattle and Horses in Jordan. Acta Vet. Brno 2002:71: 55-60.

Isolates of Trichophyton and Microsporum species are common important animal pathogens capable of causing dermatophytosis. In this report, isolation and identification of fungi causing ringworm in cattle and horses in Jordan were undertaken. Ten dairy farms and two large maintenance stables of horses located in different parts of Jordan with a history of cutaneous lesions were chosen for the present study. A complete clinical examination of 375 calves and 316 horses was performed. Skin samples were taken by scraping from 57 calves and 28 horses. Each sample was subjected to direct microscopic examination and cultured on mycobiotic agar (DIFCO) at $28{ }^{\circ} \mathrm{C}$ for $2-6$ weeks. Affected calves were treated by a locally prepared ointment containing salicylic acid, benzoic acid, sulfur and iodine in $100 \mathrm{~g}$ vaseline. Recovery rate following treatment was monitored.

Results revealed that $30.6 \%$ and $18 \%$ of infected calves and horses had clinical lesions of ringworm, respectively. Most of the lesions observed on the affected calves were alopecia and/or circumscribed grayish-white, crusty, raised lesions. These lesions commonly affected the head, neck, dewlap, and chest area. Trichophyton species and Microsporum species were the most commonly isolated fungi, with a prevalence rate of $69.01 \%$ and $8.46 \%$, respectively. All treated calves responded to topical treatment within one month. In horses, lesions were seen as round patches of 3-5 cm in diameter as raised hair and soreness spreading on the axillary girth, trunk and over the rump. Microsporum equinum and T. equinum were the most frequent fungi isolated with an incidence of $40 \%$ and $24 \%$, respectively.

Ringworm, fungal infection, dermatomycosis, cattle, horse, Jordan

Ringworm is an infectious disease of animals caused by different species of keratinophilic fungi. It is a major public and veterinary health problem reported from different parts of the world and causes great economic loss (Calderone 1989). The disease appears to be more common in tropical than temperate climates particularly in countries having hot and humid climatic condition (Pascoe 1976). It has been reported that animals housed in close proximity to each other for long periods and the presence of infected debris in buildings account for both the higher incidence and the greater infection rate in winter (Radostits et al. 1997). Trichophyton verrucosum, T. mentagrophytes and T. megninii have been regarded as the main fungi causing ringworm in cattle (Quinn et al. 1994). However, very limited studies on ringworm infection in cattle have been published from Arab countries. T. verrucosum, T. mentagrophytes and Microsporum species were the most common fungi isolated from cases of animal dermatophytosis (Abou-Gabal et al. 1976; Al-Ani et al. 1995). Abdullah and Hassan (1995) isolated T. verrucosum, M. fulvum and M. gypseum from surface sediments of the Shatt Al-Arab River of Iraq. Also, T. verrucosum has been isolated from soil in a playground in the Nablus area, West Bank of Jordan (Ali-Shtayeh 1989). In horses, Trichophyton species and Microsporum species are the main causes of ringworm in Saudi Arabia (Bagy and Abdel-Mallek 1991). In Sudan,

Address for correspondence:

Dr. F. K. Al-Ani

Faculty of Veterinary Medicine

P.O. Box: 620026 Irbid 21162

Jordan
Fax: +96227095123

@

http://www.vfu.cz/acta-vet/actavet.htm 
Abu-Samra and Ibrahim (1988) found that horses were successfully infected with human isolates of $M$. canis and $T$. violaceum.

The aims of the present study were to isolate and identify the causative fungi of ringworm in cattle and horses in Jordan, to study the epidemiology of ringworm, and to describe the clinical signs.

Animals

Materials and Methods

A total of 10 large dairy farms in different locations in Jordan were used in the present study. Each farm contained about 200-400 animals of different ages. There was a history of skin lesions on the calves close to or shortly after weaning (2.5-to-3-month-old). Also, two large maintenance stables of horses with a history of cutaneous lesions were used. The horses were of Arabian and/or Arabian-cross breed in a good nutritional state and of 2-12 years of age.

Clinical Examination

The skin of all animals was examined and a complete clinical examination of all affected animals was performed. Evaluation of the general state of the animals, temperature, pulse rate, respiratory rate, appetite and morbidity rates were recorded. The shape, size, position, distribution and time of the appearance of skin lesions as well as the age of the animals were also recorded.

Sampling

The surface of the affected area was first rubbed with a cotton swab impregnated with $70 \%$ ethyl alcohol to remove surface adhering organisms. Skin scales were collected by scraping of the margin of the lesion using a sterile scalpel blade into sterile petri dish. Hairs were collected by removing dull broken hairs from the margin of the lesion using sterile tweezers as described (Cheesbrough 1992). Each sample collected was divided into two portions. One portion was used for direct microscopic examination. The second portion was cultured on mycobiotic agar (DIFCO), incubated at $28{ }^{\circ} \mathrm{C}$ for 2-6 weeks and examined for the colony formation. To identify the pathogenic fungi macroscopic and microscopic examination was performed and included time of appearance of the growth, colony morphology, and color, shape, size and colony reverse side morphology. Microscopic examination for positive fungi cultures was done using the Lactophenol cotton blue wet mount method (Halley and Standard 1973). The slide culture technique was used when the Lactophenol cotton blue wet mount failed to show the manner in which conidia are formed and attached to the conidiophore (Al-Doory 1980). For further identification of the fungi, selective media, including Trichophyton agar number 1, 2, 3, 4 and 6 (DIFCO) was used.

Experimental infection

Two one-month-old rabbits were used. The flank area was plucked and the prepared site was scarified. A threeweek subculture of $T$. verrucosum and T. mentagrophytes grown from a clinical case from calves were macerated with normal saline to form a suspension of each strain. Inoculation was carried out with swap dipped into the inoculum of the macerated subculture and placed on the scarified area of the first and second rabbits, respectively (McGinnis 1988; Schmitt and Miller 1967). Three weeks later reisolation of the causative agent was performed.

Treatment

A total of 115 calves were treated daily for 3-5 days by ointment containing benzoic acid $6 \mathrm{~g}$, salicylic acid $3 \mathrm{~g}$, sulfur $5 \mathrm{~g}$, iodine $4 \mathrm{~g}$ and vaseline $100 \mathrm{~g}$. Six other infected calves were left without treatment to serve as controls. Calves of both groups were kept under observation following treatment for 4 months.

Statistical analysis

Means between treatment and control groups were compared by t-test. Data are presented as mean \pm SD with significant differences reported when $(P<0.05)$.

Clinical signs

Results

Among 375 calves examined, 115 (30.6\%) animals had clinical lesions of ringworm. The prevalence of ringworm infection varied from farm to farm with a range of 10 to $100 \%$. Generally, affected animals had normal temperature, pulse and respiration. Other body systems were also normal. Calves aged 3 to 7 months developed clinical signs of ringworm. The skin of affected calves showed circular, circumscribed, grayish-white, crusty raised lesions (Plate VII, Fig. 1). Focal pityrasis and alopecia were also observed. The lesions were most commonly found on the head, neck, dewlap and the chest area. 
Out of the 316 horses examined, 57 (18\%) had ringworm infection. The lesions started as patches of raised hair and soreness. Several days later, the hair detached leaving bald, gray, shining areas approximately $3 \mathrm{~cm}$ in diameter (Plate VII, Fig. 2).

\section{Causes of ringworm in calves}

Fungi isolated from cases of ringworm in calves are shown in Table 1. Trichophyton species were the most frequent genus isolated representing $69.01 \%$ of the total fungi identified in this study. Among Trichophyton species, T. verrucosum was the most commonly identified (47.88\% of the total fungi isolated). The fungi grow slowly on mycobiotic agar producing slightly folded, heaped glabrous gray white colony. On slide culture slides stained with lactophenol cotton blue, a characteristic septet hyphae with chlamydocondias arranged in chains with single microconidia were identified.

T. mentagrophytes was the second frequent isolated fungi from calves with ringworm (12.68\% of the total isolated fungi). The colony formed on mycobiotic agar after 2-4 weeks of culture at $28{ }^{\circ} \mathrm{C}$ appeared as a buff to tan thallus color and exhibited radial folds. On microscopic examination, the microconidia were pyriform in shape while the macroconidia were cigar-shaped with thin walls having a narrow attachment to the hypae containing 3-5 cells.

Other fungi isolated with low frequency included T. schoenleinii, T. terrester, T. violaceum, M. nanum, M. distortum, M. audouinii, Alternaria species, Fusarium species, Penicillium species, Cephalosporidium species and Aspergillus species (Table 1).

Table 1

Isolated fungi from calves with ringworm

\begin{tabular}{|c|c|c|c|}
\hline Animal & Isolated Fungi & No of isolation & $\%$ \\
\hline Calves & $\begin{array}{l}\text { T. verrucosum } \\
\text { T. mentagrophytes } \\
\text { T. terrester } \\
\text { T. schoenleinii } \\
\text { T. violaceum } \\
\text { M. audouinii } \\
\text { M. nanum } \\
\text { M. distortum } \\
\text { A. flavus } \\
\text { A. fumigatus } \\
\text { Alternaria sp. } \\
\text { Fusarium sp. } \\
\text { Penicillium sp. } \\
\text { Cephalosporium sp. }\end{array}$ & $\begin{array}{r}34 \\
9 \\
2 \\
3 \\
1 \\
2 \\
2 \\
2 \\
4 \\
1 \\
5 \\
4 \\
1 \\
1\end{array}$ & $\begin{array}{l}47.88 \\
12.68 \\
\\
2.82 \\
4.22 \\
1.41 \\
\\
2.82 \\
2.82 \\
2.82 \\
\\
5.63 \\
1.41 \\
\\
7.04 \\
5.63 \\
1.41 \\
1.41\end{array}$ \\
\hline Total & & 25 & 100 \\
\hline
\end{tabular}

In horses, Microsporum equinum was the most commonly isolated fungi from case of ringworm representing $40 \%$ of the total identified fungi (Table 2). Other fungi that were also isolated include Sporothrix schenckii, Alternaria sp., Aspergillus flavus and Penicillium sp. (Table 2).

\section{Experimental infection}

Rabbits experimentally infected by $T$. verrucosum and $T$. mentagrophytes resulted in the appearance of cutaneous lesions in the sites of inoculation within 3 weeks following 
infection (Plate VIII, Fig. 3). The lesions appeared as inflammatory sparse scaly areas in the site of inoculation. Samples collected and cultured on mycobiotic agar revealed the reisolation of $T$. verrucosum and T. mentagrophytes, respectively. Six weeks later, the lesions started to disappear gradually and within 9 weeks all lesions were completely healed.

Table 2

Isolated fungi from horses with ringworm

\begin{tabular}{|c|c|c|c|}
\hline Animal & Fungi Identified & No of isolation & $\%$ \\
\hline Horse & $\begin{array}{l}\text { Microsporum equinum } \\
\text { Trichophyton equinum } \\
\text { Alternaria } \mathrm{sp} \text {. } \\
\text { Sporothrix schenckii } \\
\text { Aspergillus flavus } \\
\text { A. fumigatus } \\
\text { Penicillium } \mathrm{sp} \text {. }\end{array}$ & $\begin{array}{l}10 \\
6 \\
4 \\
2 \\
1 \\
1 \\
1\end{array}$ & $\begin{array}{r}40 \\
24 \\
16 \\
8 \\
4 \\
4\end{array}$ \\
\hline Total & & 25 & 100 \\
\hline
\end{tabular}

Treatment

Effective cure of the affected calves after the topical application of the ointment was observed. Lesions started to subside gradually and after 2 weeks the hair started to grow again. Within one month there was a complete recovery. Naturally infected, non-treated calves remained infected during the entire period.

\section{Discussion}

Ringworm is a common skin disease of calves at the time of weaning. In countries bordering Jordan, the disease is quite frequently reported in Saudi Arabia, Iraq, Syria and Egypt (Abou-Gabal et al. 1976; Ali-Shtayeh et al. 1988; Bagy 1986). The disease occurred throughout the year with a higher prevalence during wintertime due to high humidity, which facilitate the growth of spores and increases the susceptibility of animals to infection (Nooruddin and Singh 1987). Our result showed that calves at weaning time are highly susceptible to ringworm infection. This may be in part due to their weak immunity and the high $\mathrm{pH}$ of their skin as the $\mathrm{pH}$ of the skin decreases with age (Rad os tits et al. 1997). Animal susceptibility is determined largely by immunological status so those young animals are most susceptible (Pascoe 1979). On the other hand, we reported that horses of different ages are susceptible to ringworm infection. This is maybe because ringworm is new to this area and the animals have no immunity against the infection. In endemic areas, it has been found that horses younger than two years were more susceptible to infection than adults (Mahmoud 1995).

Diagnosis of ringworm depends mainly upon the demonstration of the fungal agent by direct microscopic examination and culture techniques. Our results showed that only $71 \%$ of the samples examined by direct microscopic examination were positive for fungi. Other researchers reported that direct microscopic examination could provide a positive diagnosis in 40 to 60 per cent of samples from which dermatophytes are cultured (Carman et al. 1979; Sparkes et al. 1993). Also, our result showed that mycobiotic agar is a selective media for the isolation of pathogenic fungi from samples heavily contaminated with bacteria and saprophytic fungi. In calves Trichophyton verrucosum and 
T. mentagrophytes are the main causes of ringworm in Jordan $(47.88$ and $12.68 \%$, respectively) and this is similar to other parts of the world (Abou-Gabal et al. 1976; Pal 1987; Renner 1992). In horses, M. equinum and T. equinum were the most common cause of dermatophytosis in Jordan. It has been reported that in Saudi Arabia Trichophyton spp. and Microsporum spp. as the main causes of ringworm in horses (Bagy and AbdelMallek 1991). In Australia, Connole and Pascoe (1984) isolated T. equinum, T. mentagrophytes, $M$. gypseum and $M$. equinum from cases of ringworm in horses. Other researchers from different countries concluded that $T$. equinum and $M$. equinum are the main cause of ringworm in horses (Moretti et al. 1998; Stenwig 1985; Takatoria et al. 1981; Weiss et al. 1979; Woloszyn 1987).

Radostits et al. (1997) and Pal (1987) have described the clinical signs of the major dermatophytes. The main clinical lesions observed on the affected calves were suffered from alopecia and/or circular circumscribed grayish-white, crusty, raised lesions, which were most commonly found on the head, neck, dewlap, and the chest area. These findings are in agreement with those of Wabacha et al. (1998). Our results showed that rapid and effective cure of affected calves occurred with two to three applications of locally prepared ointment at 3-4-day intervals. These results are in agreement with those of Jungerman and Schwartzman (1972) who showed that sulfur in concentrations of one to ten percent is fungicidal and in contrast to Wabacha et al. (1998) who reported that calves did not respond to topical treatment with various antifungal drugs within the anticipated period of 9 weeks.

Inflammatory sparse scaly lesions developed at the flank area within three weeks after inoculation of rabbits with a suspension of $T$. verrucosum and T. mentagrophytes, respectively (Narai et al. 1988).

\section{Trichofytóza skotu a koní v Jordánsku}

Druhy rodu Trichophyton a Microsporum patří k významným patogenům zvířat schopným vyvolat dermatofytózu. Předkládaná práce se zabývá izolací a identifikací mikroskopických hub majících za následek trichofytózu skotu a koní v Jordánsku. Za tímto účelem byla sledována zvíraata pocházející z různých částí Jordánska a $\mathrm{s}$ anamnézou kožních lézí. Jednalo se o zviŕata z deseti farem skotu mléčného typu a dvou velkých udržovacích chovů koní. U 375 telat a 316 koní bylo provedeno kompletní klinické vyšetř̌ení. Od vyšetř̌ovaných zvířat byly odebrány kožní seškraby, z toho od telat 57 a od koní 28 . Každý odebraný vzorek byl podroben mikroskopickému vyšetření a kultivován na mycobiotickém agaru (fy Difco) př̀i $28^{\circ} \mathrm{C}$ po dobu $2-6$ týdnů. Postižená telata byla ošetřena na místě připravenou mastí obsahující kyselinu salicylovou, kyselinu benzoovou, síru a jód ve $100 \mathrm{~g}$ vazelíny. Po ošetření byl sledován poměr uzdravených zvířat $\mathrm{k}$ počtu nemocných. $\mathrm{Z}$ uvedených výsledků vyplývá, že $\mathrm{z}$ infikovaných telat vykazovalo klinické příznaky trichofytózy $30.6 \%$ a z infikovaných koní $18 \%$. Převážná část lézí pozorovaných u postižených telat zahrnovala alopecii či šedobílá kruhovitá ložiska zježené srsti pokrytá krustou. Tato ložiska byla nejčastěji pozorována v oblasti hlavy, krku, laloku a hrudníku. Příslušníci rodu Trichophyton a Microsporum patřili mezi nejčastěji izolované mikroskopické houby. $\mathrm{V}$ př́ipadě rodu Trichophyton byla hodnota prevalence $69,01 \%$ a u rodu Microsporum $8.46 \%$. $\mathrm{V}$ průběhu jednoho měsíce všechna ošetřená telata př́iznivě zareagovala na výše uvedenou lokální terapii. U koní byla zjištována kulatá bolestivá ložiska se zježenou srstí o průměru $3-5 \mathrm{~cm}$, šírící se na podbřišek, trup a kostrč. Microsporum equinum (incidence $40 \%$ ) a T. equinum (incidence $24 \%$ ) patřili k nejčastěji izolovaným druhům mikroskopických hub sledovaných koní. 


\section{References}

ABDULLAH S. K., HASSAN D. A. 1995: Isolation of dermatophytes and other keratinophilic fungi from surface sediments of the Shatt Al-Arab River and its creeks at Basra, Iraq. Mycoses 38:163-166

ABOU-GABAL M., EL-GALIL G. A., EL-NOR E. A., EL-REHIM D. A. 1976: Animal ringworm in Upper Egypt. Sabouraudia 14: 33-36

ABU-SAMRA M. T., IBRAHIM K. E. 1988: The effect of 9-a fluorprednisolone on the pathogenically of Microsporum canis and Trichophyton violaceum to horses. Mycoses 31: 71-79

AL-Ani F. K., AL-BASSAM L. S., AL-SALAHI K. A. 1995: Epidemiological study of dermatomycosis due to Trichophyton schoenleinii in camels in Iraq. Bull. Anim. Hlth. Prod. Afr. 43: 87-92

AL-DOORY Y. 1980: Laboratory Medical Mycology. Lea \& Febiger, Philadelphia, pp. 83-84 and 12-122

ALI-SHTAYEH, M. S. 1989: Keratinophilic fungi of schools playgrounds in the Nablus area, West Bank of Jordan. Mycopathol. 106: 103-108

ALI-SHTAYEH, M. S., ARDA, H. M., HASSOUNA, M., SHAHEEN, S. F. 1988: Keratinophilic fungi on the hair of cows, donkey, rabbits, cats and dogs from the West Bank of Jordan. Mycopathol. 104:109-121

BAGY, M. M. 1986: Fungi on the hair of large mammals in Egypt. Mycopathol. 93: 73-75

BAGY, M. M., ABDEL-MALLEK, A. Y 1991: Saprophytic and keratogenic fungi associated with animal's hair from Riyadh, Saudi Arabia. Zbl. Mikrobiol. 146: 305-310

CALDERONE, R. A.1989: Immunoregulation of dermatophytosis. Crit. Rev. Microbiol. 16: 339-368

CARMAN, M. G., RUSH-MUNRO, F. M., CARTER M. E. 1979: Dermatophytes isolated from domestic and feral animals. N. Z. Vet. J. 27:136

CHEESBROUGH, M. 1992: Medical Laboratory Manual for Tropical Countries. Volume 2. Tropical Health Technology, Butterworth-Heinemann, Great Britain, pp. 371-385

CONNOLE, M. D., PASCOE R. R. 1984: Recognition of Trichophyton equinum var. equinum infection of horses. Aust. Vet. J. 61: 94

HALLEY, L. D., STANDARD, P. G. 1973: Laboratory Methods in Medical Mycology, $3^{\text {rd }}$ Ed. U S Department of Health, Education and Welfare, Center of Disease Control, Atlanta, pp 41- 57

JUNGERMAN, P. F., SCHWARTZMAN, R. M. 1972: Veterinary Medical Mycology, Lea \& Febiger, Philadelphia, pp. 3-28

MAHMOUD, A. 1995: Dermatophytes and other keratinophilic fungi causing ringworm of horses. Folia Microbiol. 40: 293-296

MCGINNIS, M. R. 1988: Current Topics in Medical Mycology, Vol. 1, Springer-Verlag, New York, pp. 261-265

MORETTI, A., BONCIO, L., PASQUALI, P. FIORETTI, D. P. 1998: Epidemiological aspects of dermatophyte infections in horses and cattle. Zentbl. Vet. Med. B45: 205-258

NARAI, K., NUNER, E., RODRIGUEZ, H., GONZALEZ, M., ALBARI, V. SARKISOV, K. A. 1988: Use of ringworm vaccine „LTF-130“ in the Republic of Cuba. Veterinariya 6: 61-62

NOORUDDIN, M., SINGH, B. 1987: Dermatophytosis in buffaloes, cattle and their attendants. Mykosen 30: 594600

PAL, M. 1987: Dermatophytosis in cattle, clinical and mycological studies. Indian J. Anim. Sci. 57: 856-857

PASCOE, R. R. 1976: Studies on the prevalence of ringworm among horses in racing and breeding stables. Aust. Vet. J. 52: 419-421

PASCOE, R. R. 1979: The epidemiology of ringworm in racehorses caused by Trichophyton equinum var. autotrophicum. Aust. Vet. J. 55: 403-407

QUINN, P. J., CARTER, M. E., MARKEY, B., CARTER, G. R. 1994: Clinical Veterinary Microbiology, $1^{\text {st }}$ Ed, Wolfe Publishing, London, pp.1164-1167

RADOSTITS, O. M., BLOOD, D. C., GAY, C. C. 1997: Veterinary Medicine, $8^{\text {th }}$ Ed, Bailliere Tindall, London, pp. 381-390

RENNER, J. E. 1992: A new treatment for ringworm in cattle. Dtsche Tierarztliche Wchsch. 99: 208-210

SCHMITT, J. A., MILLER, R. G. 1967: Variation in susceptibility to experimental dermatomycosis in genetic strains of mice. Mycopathol. 32: 306-312

SPARKES, A. H., GRUFFYDD, T. J., SHAW, S. E., WRIGHT, A. I., STOKES, C. R. 1993: Epidemiological and diagnostic features of canine and feline dermatophytosis in the United Kingdom from 1956 to 1991. Vet. Rec. 133: $57-61$.

STENWIG, H. 1985: Isolated dermatophytes from domestic animals in Norway, Nord. Vet. Med. 37:161-169

TAKATORIA, K., ICHIJO, S., KONISHI, T., TANAKA, I. 1981: Occurrence of equine dermatophytosis in Hokkaido. J. Vet. Sci. 43: 307-313

WABACHA, J. K., GITAU, K. J., BEBORA, L. C., BWANGA, C. O., WAMURI, Z. M. MBITHI, P. M. 1998 : Occurrence of dermatomycosis (ringworm) due to Trichophyton verrucosum in dairy calves and its spread to animal attendants. J. S. Afr. Vet. Assoc. 69: 172-173

WEISS, R., BOHM, K. H., MUMME, J., NICKLAS, W. 1979: Dermatophytennachweise in den Jahren 1965 bis 1977. Sabouraudia 17: 345-353

WOLOSZYN, S. 1987: Fungicidal activity of iodophores in the arthrospores of dermatophytes. Polskie Archiwum Weterynaryjne 27: 25-3 
Plate VII

Al-Ani F. K. et. al.: Ringworm ... pp. 55-60

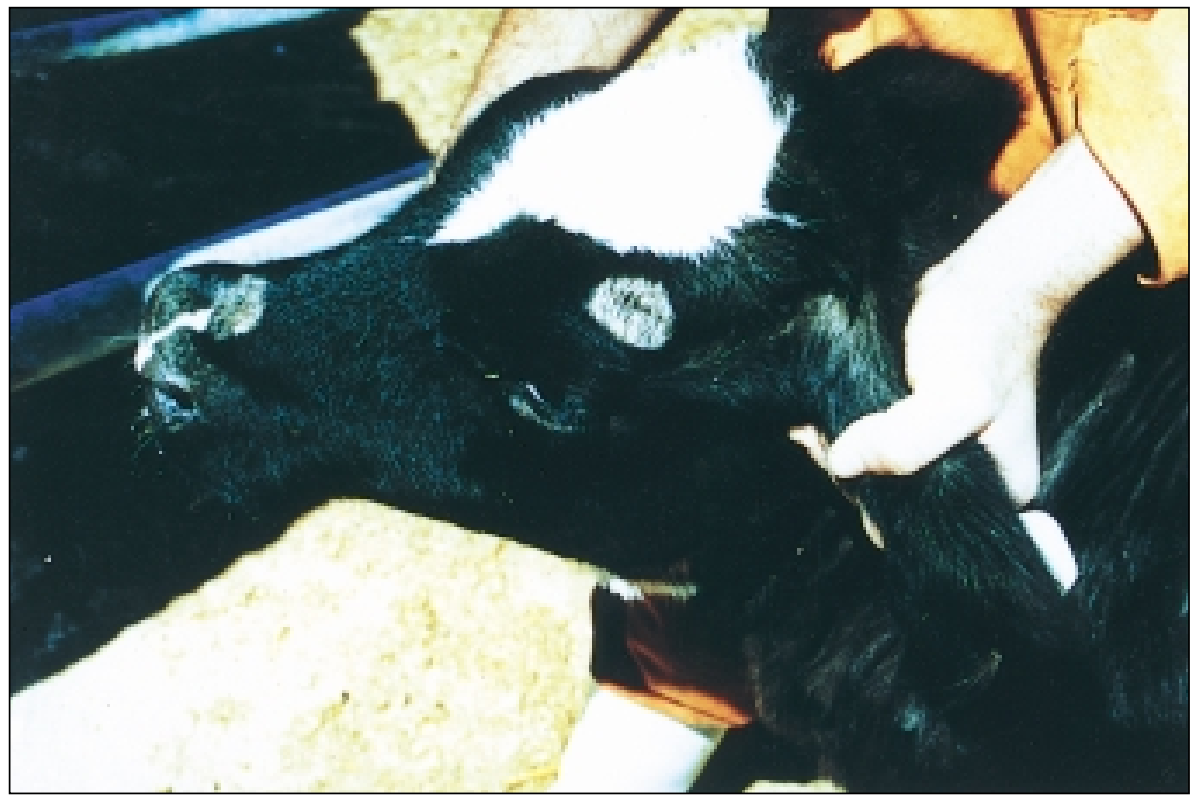

Fig. 1. A 4-month-old calf with cutaneous lesions of ringworm.

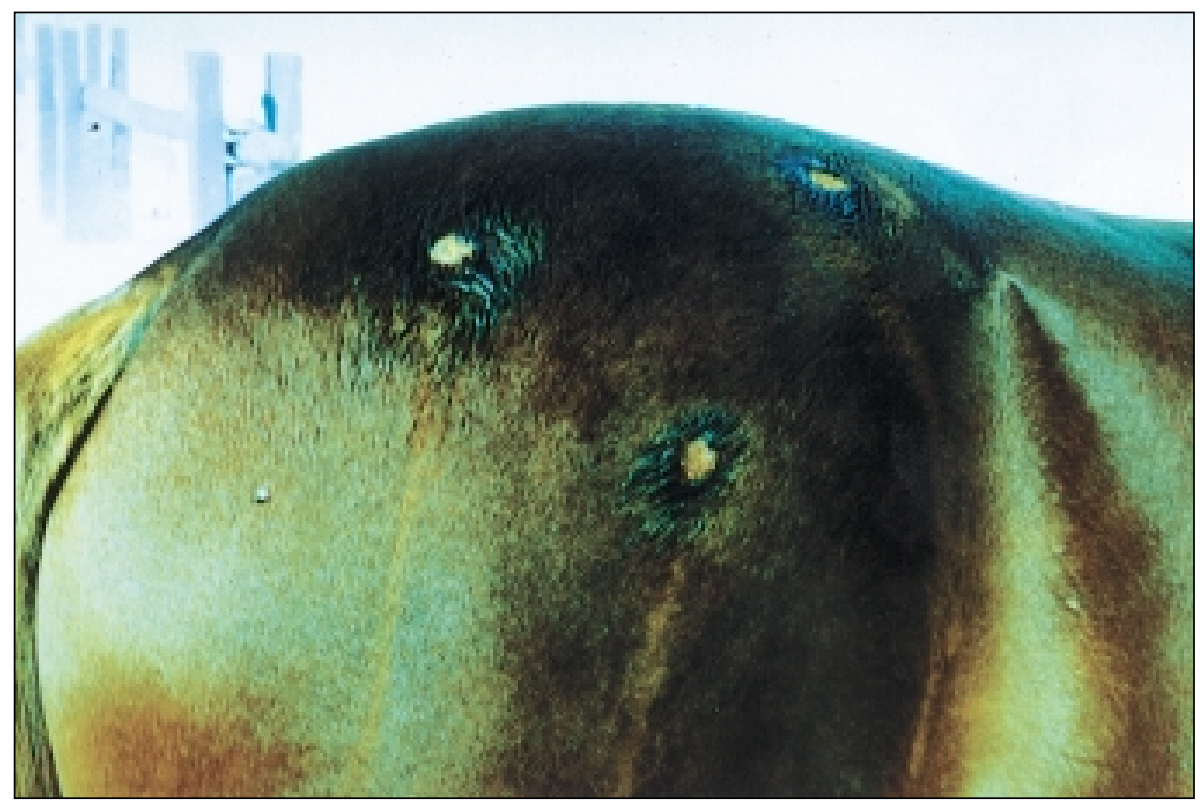

Fig. 2. Round patches - lesions on the back of a horse with ringworm infection. 
Plate VIII

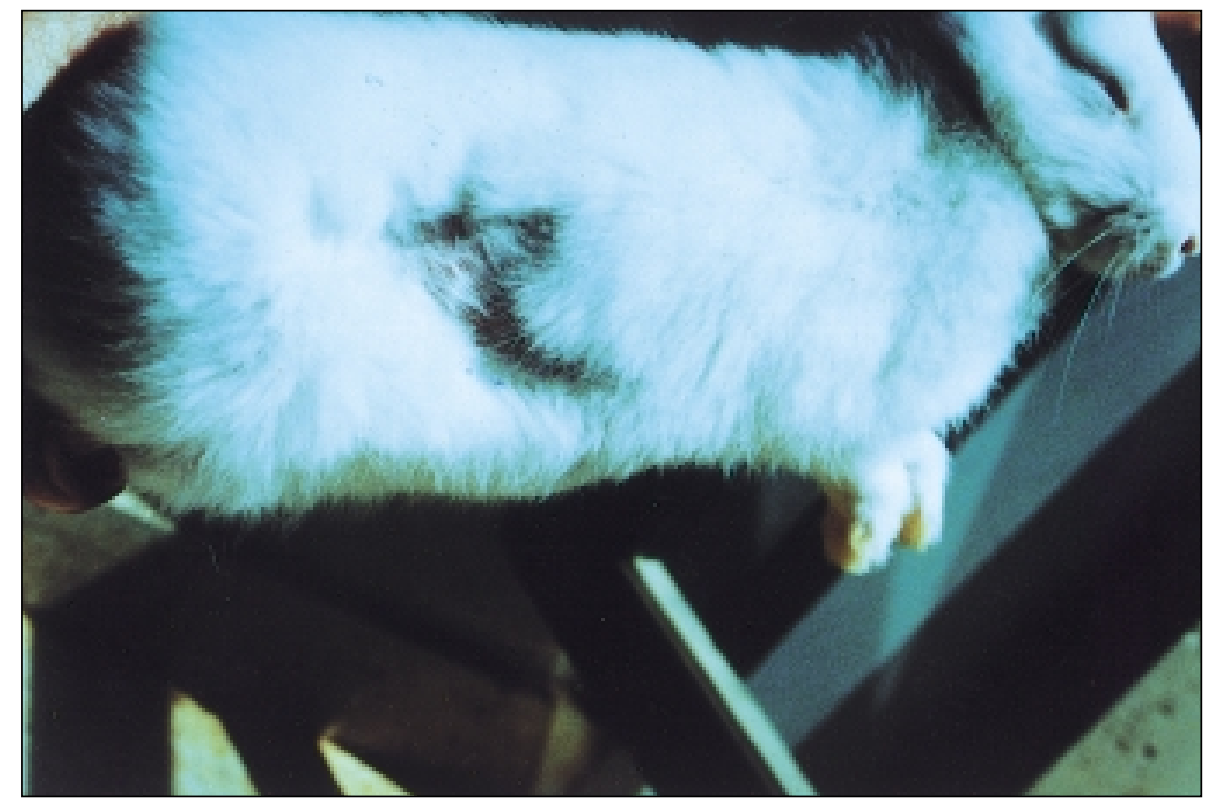

Fig. 3. A 1-month-old rabbit experimentally infected with $T$. verrucosum. 